\title{
PARTICULATE MATTER INVESTIGATION IN INDOOR ENVIRONMENT
}

\section{A. EŠTOKOVÁ* \\ N. ŠTEVULOVÁ \\ L. KUBINCOVÁ}

Received: $18 / 12 / 09$

Accepted: 09/02/10

\author{
Technical University of Košice Civil Engineering Faculty \\ Institute of Building and Environmental Engineering \\ Vysokoškolská 4, 04200 Košice, Slovakia
}

*to whom all correspondence should be addressed: e-mail: Adriana.Estokova@tuke.sk

\begin{abstract}
Particulate matter is one of the most important indoor air pollutants involved in a number of adverse health effects, such as premature deaths and increased mortality of infants and other parts of sensitive population.

This paper focuses on investigation of metal substances of suspended as well as settled particulate matter in indoor environment. The monitoring of particulate matter concentration was carried out in three rooms of a selected flat building in the city of Košice, Slovakia. The sampling of settled particulate matter was carried out by passive methods during the period of 28 days. The investigation of suspended particulate matter investigation focused on total suspended particles (TSP) and thoracic fraction called $\mathrm{PM}_{10}$. The presence of selected metals in the samples was detected by atomic absorption spectrometry.

The surface concentrations of settled particulate matter were detected in the range from $276.43 \mathrm{\mu g} \mathrm{cm}^{-2}$ to $570.70 \mathrm{\mu g} \mathrm{cm}^{-2}$, mass concentrations of total suspended particulate matter from 59.028 to $114.583 \mu \mathrm{g} \mathrm{m}^{-3}$. $\mathrm{PM}_{10}$ concentration values reached about half of the TSP concentration values (PM10/TSP ratio was from 0.48 to 0.6 ). Higher percentage of metals was detected in suspended particulate matter in comparison to the settled particles. Higher values were detected for all metals (except iron and zinc) in each measured room.
\end{abstract}

KEYWORDS: $\mathrm{PM}_{10}$, aerosol, metals, deposition.

\section{INTRODUCTION}

Hazardous influence of particles is related to their penetration and deposition into human respiratory system. Indoor particle concentration depends on penetration of outdoor particles into the indoor environment and on the intensity of indoor aerosol sources. The behaviour of indoor aerosols is affected by the structural system of a building, material characteristics, the way of air exchange, the operating mode of indoor environment in the presence of inhabitants. The structural systems of a building along with physical properties of the outdoor air (wind direction and intensity, the difference in the density of the indoor/outdoor air, the difference in the indoor/outdoor air temperatures etc.) determine interzonal transport of pollutants (Diapouli et al., 2008). In multi-floor buildings the flow induced by buoyancy influences the motion of contaminated air within the building. Mechanical and/or natural ventilation and infiltration define air exchange rate, and thereby the amount of outdoor particles penetrating into the building interior. The efficiency of filters integrated in mechanical ventilation systems and natural ventilation by open windows allow the estimations of particle penetration in dependence on outdoor aerosol concentration, whereas infiltration through cracks in the building shell is uncontrolled and depends not only on physical properties of contaminated air but mainly on particle deposition on surface cracks (Colliver and Fellow, 2000; Thatcher et al., 2001; 2003; Liu and Nazaroff, 2003).

Operation, the number and behaviour of inhabitants i.e. type, emission intensity and the amount of indoor contamination sources determine temporal and spatial variations of indoor aerosol distribution. In addition, wet processes as cleaning, washing, drying and ironing 
increase relative humidity which can lead to variations in particle size distribution. Indoor furnishing level increases deposition surface area (Thatcher et al., 2002). Physical properties of employed building materials such as thermal conductivity influence surface-to-air temperature difference, thermal convection and thermophoresis (or thermoprecipitation). This process is significant in the winter season when constructions separate heated areas from the unheated ones. Chemical composition can influence the appearance of the electrostatic charge. The total aerosol concentration is determined by the balance between source emissions and aerosol decay due to indoor air chemical processes and aerosol loss mechanisms (Thatcher et al., 1995).

Particle deposition is considered to be a dominant mechanism of losses of particles suspended in the indoor air (Sverrák, 2004). It strongly depends on the size of the particle, the presence of airflow, surface area and its characteristics, surface-to-volume ratio and surface charge. The deposition that occurs indoor involves six basic mechanisms: diffusion, inertial impaction, gravitational settling, interception, termophoresis and electrostatic attraction (Hinds,1999). For very small particles, particle diffusion toward the surfaces is dominant. Gravitational settling is significant for larger particles (Crump et al.,1983; Jesenák, 2008; Morawska and Salthammer, 2004).

Because of the inhalation exposure the chemical composition of the particulate matter implies toxic health effect on human organism. The presence of metal substances is considered to be a significant factor of health risk. The metal contamination of indoor air is affected by contribution from outdoor particle penetration as well as indoor sources (smoking) and possible emission from building materials in old buildings. Metal source emissions in outdoor environment originate from gasoline additives, the combustion of fossil fuels, various industrial processes such as steel and iron manufacturing and nonferrous metal production as main sources of heavy metals (e.g., for $\mathrm{Pb}, \mathrm{Cu}, \mathrm{Ni}, \mathrm{Zn}$, and $\mathrm{Cd}$ ). $\mathrm{Si}, \mathrm{Al}$, and $\mathrm{Fe}$ were found also in the form of various minerals, as well as soluble elements $\mathrm{Ca}, \mathrm{Mg}, \mathrm{Na}$, and $\mathrm{K}$ in soil and crustal component. Contribution from soil and crustal components depends on the geology of the region and climate (EPA, 2004; Fowles et al., 2003).

Cigarette smoke contains more than 4000 chemicals out of which about 70 different cancer causing substances including heavy metals arsenic, cadmium and chromium (Suna et al., 1991). According to studies of contamination of heavy metals in indoor air from tobacco smoking, the detected $\mathrm{Pb}$ level was slightly higher in smoky places than outdoors (EPA).

The presence of metals from building structures can be generated mostly by friction of structure surfaces. Old paint can be the source of airborne heavy metal as lead $\mathrm{Pb}$ and indoor latex paints can emit mercury vapours. Significant quantities also emerged in glaze and stained glass. At the present time these substances are banned; however, they can be present in old buildings. The occurrence of heavy metals suspended in the indoor aerosol was partially studied in our previous works (Števulová et al., 2002; 2003).

This paper is a cause study aiming at investigation of metal substances of suspended as well as settled particulate matter in indoor environment in a selected flat building.

\section{METHODS}

The monitoring of aerosol concentration was carried out in three rooms of the selected flat building in the city of Košice in Slovakia. Kitchen, living room and working room as representative indoor environments with different indoor sources were chosen. Environmental tobacco smoke was the major source of the particles in the living room. In the kitchen equipped with a gas stove cooking was considered to be the major source of particulate matter. No significant indoor source was determined in the working room. However, the penetration of outdoor particles through large openings (windows, doors) or cracks and gaps through the body of the building and interzonal transport from other rooms cannot be neglected.

The sampling of settled particulate matter was carried out by passive methods during the period of 28 days in March 2008. The adjusted sampling method for ambient air was used; aerosol particles were captured into Petri dishes $(8,5 \mathrm{~cm}$ in diameter) installed in three height 
levels. The results of the study focusing on the relationship between particulate concentration and height level of their sampling were published before (Kubincová et al., 2008).

The particles settled in Petri dishes were converted into distilled water solution which was consequently filtered through a membrane filter in order to detect insoluble solid portion of the total settled mass. Three samples (filters) of settled particles from every room were obtained. After drying of the filters, insoluble solid portion of settled particles was determined by gravimetric method (measured by analytical balance within $0.0001 \mathrm{~g}$ ) from filter weight increase. Furthermore, the presence of selected metals in the insoluble solid portion was detected by atomic absorption spectrometry (SpectrAA-30, Varian, Australia). Fe, Zn, and $\mathrm{Cu}$ were detected by a standard process in acetylene - air flame, $\mathrm{Cd}, \mathrm{Cr}, \mathrm{Ni}, \mathrm{Pb}$ and $\mathrm{Co}$ were detected in graphite cell in the add-on equipment GTA 96. Arsenic content was detected by the hydride method in the VGA 76 add-on equipment.

The investigation of suspended particulate matter focused on total suspended particles (TSP) and thoracic fraction $\mathrm{PM}_{10}$. The investigation was carried out in the same rooms in the flat building in the city of Košice in March 2008. The measurement includes integral particles sampling onto a collection material (membrane filter Synpor 0,83 $\mu \mathrm{m}$ pore size, $35 \mathrm{~mm}$ in diameter) with sampling equipment VPS 2000 (Envitech, Trenčín) at air flow of 600 litres/hour during the sampling period of approximately 24 hours. Because of minimization of humidity interference and VOC elimination, the filters were dried at $105^{\circ} \mathrm{C}$ for $8 \mathrm{~h}$ before sampling, subsequently equilibrated at a constant temperature and humidity (e.g. $20^{\circ} \mathrm{C}$ and $50 \% \mathrm{RH}$ ) for $24 \mathrm{~h}$ before and after sampling. The particulate mass concentrations were determined by gravimetric method from the increase of filter weight (measured by analytical balance within $0.00001 \mathrm{~g}$ ). Subsequently, selected metal concentrations were detected by AAS in the samples.

The morphology of settled as well as suspended particulate matter was investigated by the electron scanning microscopy (SEM) with the equipment Jeol JSM-35CF (Japan).

\section{RESULTS AND DISCUSSION}

The concentrations of indoor particulate matter measured in the indoor environment are summarized in table 1. Settled particulate matter occurrence is presented for each room from all height levels together expressed as total deposited mass surface concentration. Suspended particulate matter in the air was monitored as total suspended particles TSP and fraction $\mathrm{PM}_{10}$ and presented as mass concentrations.

Settled particulate matter was investigated for the insoluble solid portion. The ratio of insoluble solid portion presented in Table 1 was obtained by dividing the weight of insoluble solid portion of settled particles by the total settled particles mass weight.

Table1. Settled particulate matter and suspended particulate matter concentrations

\begin{tabular}{lrrr}
\hline & Kitchen & Living room & $\begin{array}{c}\text { Working } \\
\text { room }\end{array}$ \\
\hline Total mass of settled particles $\left[\mathrm{\mu g} \mathrm{cm}^{-2}\right]$ & 570.70 & 351.59 & 276.43 \\
\hline Insoluble solid portion of the total settled mass [\%] & 38.10 & 71.40 & 33.90 \\
\hline Total suspended particulates TSP $\left[\mu \mathrm{\mu} \mathrm{m}^{-3}\right]$ & 80.56 & 114.58 & 59.03 \\
\hline $\mathrm{PM}_{10}\left[\mathrm{\mu g} \mathrm{m}^{-3}\right]$ & 48.61 & 55.56 & 31.94 \\
\hline $\mathrm{PM}_{10} / \mathrm{TSP}$ ratio & 0.60 & 0.48 & 0.54 \\
\hline
\end{tabular}

As can be seen in the Table 1, because of the existence of indoor particulate sources, the highest total deposited mass was detected in the kitchen. It was expected to be the highest insoluble solid portion of settled particles. But there was detected the highest percentage of insoluble solid portion of settled particles in the living room. The fibres from carpets, textile and upholstered furniture represented the essential part of insoluble solid portion of settled particles.

Unlike the results of settled particulate matter, the highest concentration of total suspended particles as well as $\mathrm{PM}_{10}$ fraction was noticed in the living room (Table 1). The concentration 
of $\mathrm{PM}_{10}$ measured in the living room exceeds the hygienic limit for indoor air in the Slovak Republic $\left(50 \mu \mathrm{g} \mathrm{m}^{-3}\right)$. The $\mathrm{PM}_{10}$ concentration values reached about half of the TSP concentration values $\left(\mathrm{PM}_{10} / \mathrm{TSP}\right.$ ratio 0.48 for the living room, 0.60 for the kitchen and 0.54 for the working room).

The scanning electron microscopy (SEM) micrographs represent the morphology of the selected particles. As shown in Figure 1, the particles with irregular shapes and various particle sizes were observed in the sample of settled particulate matter. Individual particles and also the aggregates of fine particles were observed in $\mathrm{PM}_{10}$ suspended particulate matter (see Figure 2).

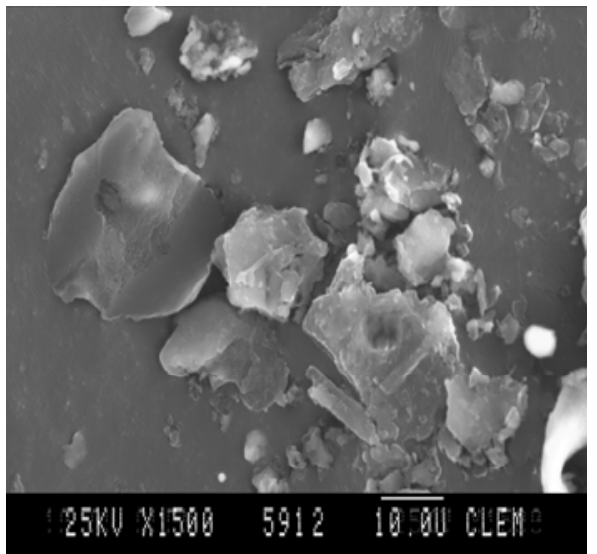

Figure 1. Settled particulate matter

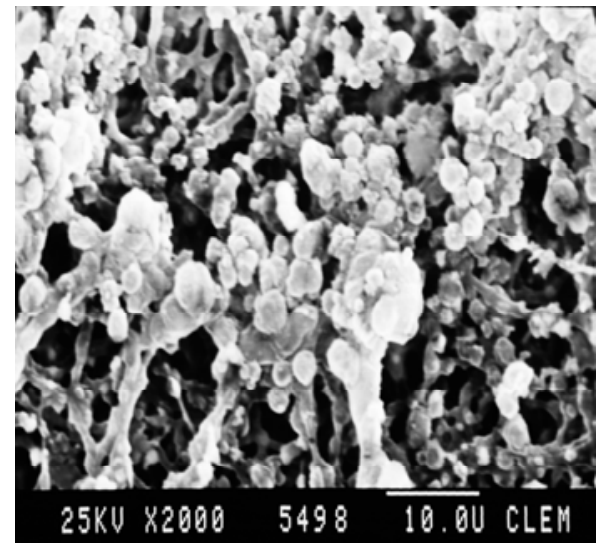

Figure 2. $\mathrm{PM}_{10}$ particles morphology

The metal content was investigated in both settled and suspended particulate matter samples. Because of the low quantity in the samples of the suspended particles, the metal concentrations were detected for TSP and $\mathrm{PM}_{10}$ filters all at once. The results of AAS analysis of selected metal content in settled and suspended aerosols for each monitored room are presented as metal concentrations in Table 2 and Table 3 . The average concentrations from monitored rooms for metals which were measured in insufficient amount for individual concentration detection for each room are presented for arsenic, cadmium, chromium, nickel and lead.

Table 2. Surface metal concentrations in settled particulate matter $\left[\mu \mathrm{g} \mathrm{cm}^{-2}\right]$

\begin{tabular}{llll}
\hline \multicolumn{1}{c}{ Metal } & Kitchen & Living room & $\begin{array}{c}\text { Working } \\
\text { room }\end{array}$ \\
\hline Calcium & 0.64 & 1.46 & 2.06 \\
\hline Copper & 0.04 & 0.06 & 0.07 \\
\hline Iron & 2.56 & 1.78 & 4.73 \\
\hline Magnesium & 0.22 & 0.50 & 0.67 \\
\hline Zinc & 0.29 & 2.80 & 0.91 \\
\hline \multicolumn{4}{c}{ Average concentration } \\
\hline Arsenic & 0.10 \\
\hline Cadmium & 0.03 \\
\hline Chromium & 0.04 \\
\hline Nickel & 0.05 \\
\hline Lead & 0.09 \\
\hline
\end{tabular}

The surface metal concentrations of settled particulate matter were detected in the range from $0.03 \mu \mathrm{g} \mathrm{cm}^{-2}$ (cadmium) to $4.73 \mu \mathrm{g} \mathrm{cm}$ (iron). The highest concentrations were measured in the case of iron, calcium and zinc. There were no significant differences of metal surface concentrations found in measured rooms. The metal concentration of the other investigated metals $(\mathrm{Cr}, \mathrm{Ni}, \mathrm{Pb}, \mathrm{Cd}, \mathrm{As})$ in settled particulate matter was low, close to the detection limit (Table 2). The significant high concentrations of cadmium, chromium, arsenic 
and lead as tobacco smoke emissions were not confirmed in settled particulate matter. The mass metal concentrations in suspended particulate matter range from $0.07 \mu \mathrm{g} \mathrm{m}^{-3}$ (cadmium) to $2.47 \mathrm{\mu g} \mathrm{m}^{-3}$ (calcium). Similarly to settled particulate matter's metal concentrations, no significant differences were measured for the monitored rooms.

Table 3. Mass metal concentrations in suspended particulate matter $\left[\mu \mathrm{g} \mathrm{m}^{-3}\right]$

\begin{tabular}{lccc}
\hline \multicolumn{1}{c}{ Metal } & Kitchen & $\begin{array}{c}\text { Living } \\
\text { room }\end{array}$ & $\begin{array}{c}\text { Working } \\
\text { room }\end{array}$ \\
\hline Calcium & 2.16 & 2.47 & 1.56 \\
\hline Copper & 0.18 & 0.10 & 0.16 \\
\hline Iron & 0.14 & 0.51 & 1.71 \\
\hline Magnesium & 0.41 & 0.51 & 0.37 \\
\hline Zinc & 0.20 & 0.21 & 0.20 \\
\hline \multicolumn{4}{c}{ Average concentration } \\
\hline Arsenic & \multicolumn{3}{c}{0.28} \\
\hline Cadmium & 0.07 \\
\hline Chromium & \multicolumn{3}{c}{0.10} \\
\hline Nickel & & 0.14 \\
\hline
\end{tabular}

The found mass of metal contents in the samples of settled as well as suspended particulate were compared to the total mass of monitored particulate matter for each monitored room. Figure 3 represents the percentage content of metal in settled particulate matter for each monitored room; Figure 4 represents the percentage content of metal in suspended particulate matter. The average concentration for percentage content of arsenic, cadmium, chromium, nickel and lead are presented in Figure 5.

In comparison to the settled particles, higher percentage of metals was detected in suspended particulate matter. The higher values were found for all metals (except iron and zinc) in each measured room. This finding may be the result of the fact that metals are cumulated in the finest fraction of aerosols (Asmi et al., 2000, Števulová, 2003) represented by suspended $\mathrm{PM}_{10}$ in this study. The percentage of metals in indoor aerosols is lower or comparable to the values measured for outdoor aerosols (Bobro and Hančulák, 2006; Máčala and Kozáková, 2004).

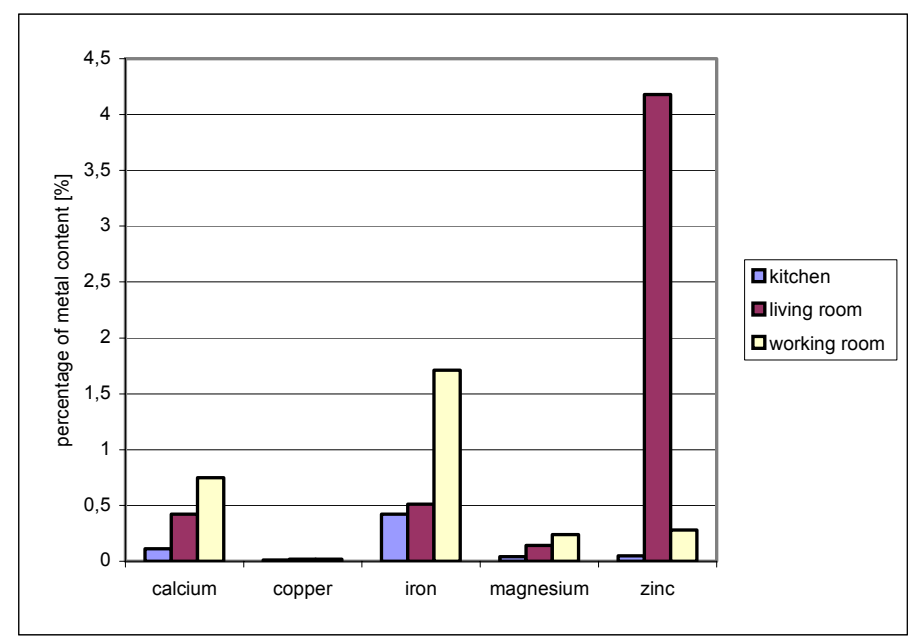

Figure 3. Percentage content of metal in settled particulate matter for monitored rooms 


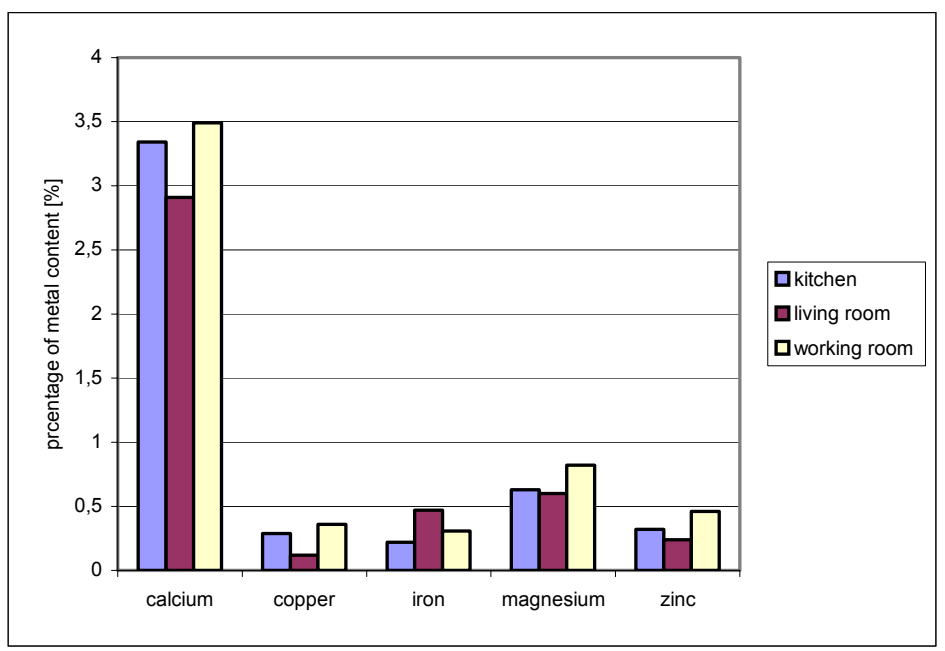

Figure 4. Percentage content of metal in suspended particulate matter for monitored rooms

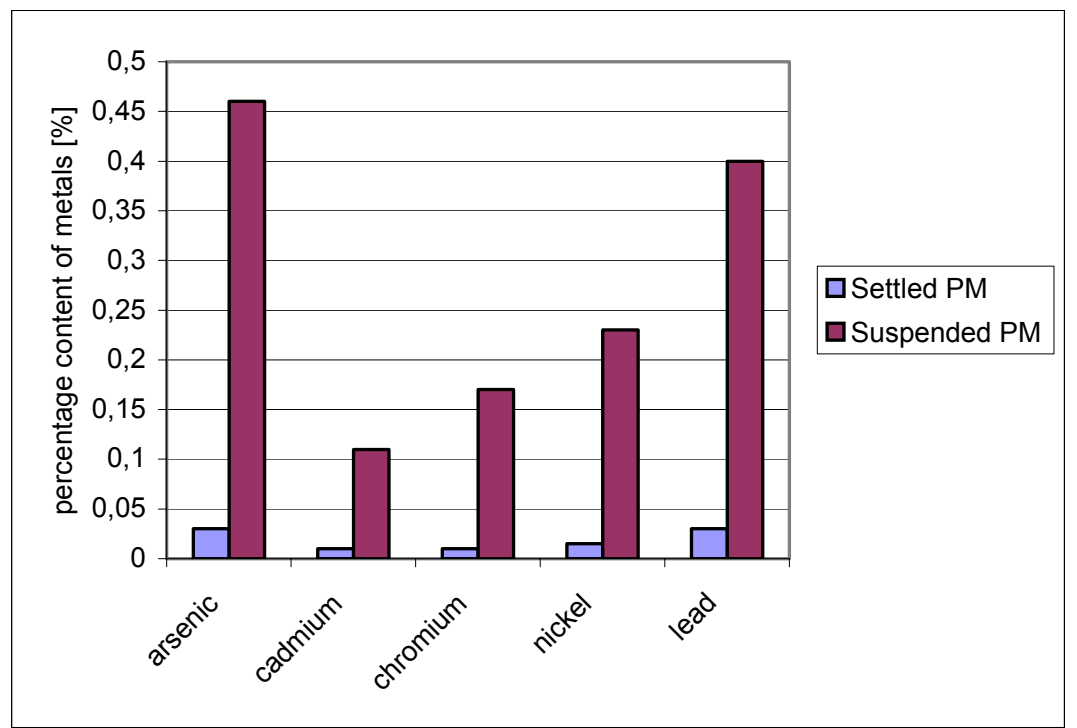

Figure 5. Percentage content of metals in settled and suspended particulate matter

\section{CONCLUSIONS}

The indoor settled as well as suspended particulate matter was monitored and metal content investigation was performed. There were no significant differences of metal content found in measured rooms (except zinc). In comparison to the settled particles, higher percentage of metals was detected in suspended particulate matter. The significant high concentrations of cadmium, chromium, arsenic and lead were not measured and the significance of tobacco smoke as dominate indoor metal source was not confirmed in this study.

\section{ACKNOWLEDGEMENTS}

This work was funded by project ITMS 26220120018 „ The Support to the Centre of Excellent Integrated Research into Progressive Building Structures, Materials and Technologies.

\section{REFERENCES}

1. Asmi A. et al., (2000), Connection between ultra-fine aerosols indoors and outdoors in an office environment, Proceeding of Healthy Buildings 2000: International Conference, 2000, Helsinky, Finland. 543-548.

2. Bobro M. and Hančulák J. (2006), Fine-dispersed materials. Košice: SAV, ISBN 80-7166-0442. (in Slovak) 
3. Colliver D.G. and Fellow P.E.A (2000), Predictive method to determine the leakage area needed in residences for IAQ control by infiltration. CIBSE Conference Papers - Dublin 2000.

4. Consumer Product Safety Commission, American Medical Association, Environmental Protection Agency and the American Lung Association, Indoor Air Pollution. Introduction for Health Professionals, CPSC Document \#455

5. Crump J.G., Flagan R.C. and Seinfeld J.H. (1983), Particle wall loss rates in vessels, Aerosol Sci. Technol., 2, 303-309.

6. Diapouli E. et al., (2008), Indoor and outdoor PM concentrations at a residential environment in the Athens area, Global NEST Journal, 10, 201-208.

7. Environmental Protection Agency (2004), Air Quality Criteria for Particulate Matter, USA, October, EPA/600/P-99/002aF

8. Fowles J., Phillips D. and Kaiserman M. (2003), Chemical Composition of Tobacco and Cigarette Smoke in Two Brands of New Zealand Cigarettes. Prepared as part of a New Zealand Ministry of Health Report, August, 2003.

9. Hinds W.C. (1999) Aerosol Technology: Properties, behaviour and measurement of Airborne Particles. USA: WILEY-INTERSCIENCE, John Wiley and Sons, 483 p. ISBN 0-471-19410-7.

10. Jesenák K. (2008), Analysis of particle size, Slovakia: Bratislava, PF UK, ISBN 978-80-2232464-9, http://www.fns.uniba.sk/?jesenak2008. (in Slovak)

11. Kubincová L., Eštoková A. and Števulová N. (2008) Aerosols Deposition onto Horizontally Oriented Indoor Surfaces - the case study, Selected Scientific Papers, 3(1), 89-96.

12. Liu D. and Nazaroff W.W. (2003), Particle Penetration through Building Cracks, Aerosol Science \& Technology, 37, 565-573.

13. Mačala J., Kozáková L. and Kuzevičová Ž. (2004), Monitoring of air pollution in Slovakia, Acta Avionica, 6(9), 91-96.

14. Morawska, L. and Salthammer, T. (2004), Indoor Environment: Airborne Particles and Settled Dust. USA: WILEY-INTERSCIENCE, John Wiley and Sons, 2004, $467 \mathrm{p}$.

15. Svěrák, T. (2004), Sorption purpose lime hydrate grinding, Int. J. of Mineral Proces, 74, 379383.

16. Števulová N., Eštoková A. and Bálintová M. (2002), The heavy metals occurrence in indoor air Proceeding of 13th Conference Indoor clima and buildings, Štrbské Pleso, 19.-20.11.2002. Bratislava: SSTP Bratislava, 2002. 125-130. ISBN 80-967479-5-9. (in Slovak)

17. Števulová N., Eštoková A. and Bálintová M. (2000), Dust in indoor environment, In: Proceeding of the $3^{\text {rd }}$ scientific seminar Particulate matter in science, practice and environment, 6 December, 2000, Košice: Technical university 2000. 83-86. ISBN 80-7099621-8. (in Slovak)

18. Števulová N., Eštoková A. and Šenitková I. (2003), Monitoring and characterisation of indoor particulate matter. Proceedings of the 14th international conference Air Quality - Assessment and Policy at Local, Regional and Global Scales:, Dubrovnik, 6-10 October, 2003 Zagreb: CAPPA, 2003. p. 331-337. ISBN 953-6609-03-7.

19. Suna S., Asakawa F., Jitsunari F., Manabe Y., Gotou A., Fukunaga I. and Nakajima T. (1991), Assessment of cadmium and lead released from cigarette smoke, Japanese journal of hygiene, 46(5), 1014-24.

20. Thacher T.L. and Layton D.W. (1995), Deposition, resuspension, and penetration, of particles within a residence. J. Atmospheric Environment, 29, 1487-1497.

21. Thatcher T.L. and McKone T.E., Fisk W. ., Sohn M.D., Delp W.W., Riley W.J. and Sextro R.G. (2001), Factors Affecting the Concentration of Outdoor Particles Indoors (COPI): Identification of Data Needs and Existing Data, Report Number LBNL-49321. December 2001.

22. Thatcher T.L., Lunden M.M., Revzan K.L., Sextro and R.G., Brown N.J. (2003), A Concentration Rebound Method for Measuring Particle Penetration And Deposition in The Indoor, Aerosol Science \& Technology, 37, 847 - 864.

23. Thatcher T.L., Lai A.C.K., Moreno-Jackson R., Sextro R.G., Nazaroff W.W. (2002), Effects of room furnishings and air speed on particle deposition rates indoors, Atmospheric Environment, 36(11), 1811-1819. 